\title{
Dielectric and Electrochemical Properties of Sustainable Concrete
}

\author{
R. Corral-Higuera ${ }^{\mathrm{a}}$, S. P. Arredondo-Rea ${ }^{\mathrm{a}}$, M.A. Neri-Flores ${ }^{\mathrm{b}}$, V. Orozco-Carmona ${ }^{\mathrm{b}}$, J. \\ M. Gómez-Soberón ${ }^{\mathrm{c}}$, F. Almeraya-Calderón ${ }^{\mathrm{b}}$, J. L. Almaral-Sánchez ${ }^{\mathrm{a}}$ \\ ${ }^{a}$ Universidad Autónoma de Sinaloa, Facultad de Ingeniería Mochis, \\ Fuente de Poseidón y Ángel Flores s/n, Ciudad Universitaria, C.P. 81223, Los Mochis, \\ Sinaloa, México. \\ b Centro de Investigación en Materiales Avanzados, S.C., Ave. Miguel de Cervantes 120, \\ Complejo Industrial Chihuahua, C.P. 31109, Chihuahua, Chihuahua, México. \\ c Universidad Politécnica de Cataluña, Departamento de Construcciones Arquitectónicas \\ II, Avenida Gregorio Marañón 44-50, Z.C. 08028, Barcelona, España.
}

It is planned to improve the durability of reinforced concrete structures and the total or partial replacement of their components by the use of recyclable materials; as strategies to contribute to the concrete industry sustainability. The electrical resistivity and its relationship with the microstructure and electrochemical corrosion resistance in reinforced concrete manufactured with sustainable characteristics, that is, with recycled aggregates and supplementary cementitious materials; was evaluated in this study. The electrical resistivity in reinforced concretes is closely related to the microstructure of the cementitious matrix, and with the pore structure and distribution. As a consequence of the their components nature, it is assumed that the proposed sustainable concretes present different microstructure and porosity than the conventional concretes; because of this, the electrical and electrochemical response of those systems was analyzed with the help of the electrochemical impedance spectroscopy technique.

\section{Introduction}

Nowadays, as a result of the significant environmental impact caused by the manufacture process of concretes and, as contribution to this industry, sustainability, it is being implementing improvements in its durability, as well as, the replacement of their components by less-aggressive recyclable materials. Some of the alternative materials more used in the concrete manufacture are those which partially replace the Portland cement (Supplementary Cementitious Material [SCM]), i.e. silica fume (SF), fly ash (FA) and the blast furnace slag; concerning the aggregates, the recycled concrete aggregates are employed as replacement of the natural aggregates. At present there are an important number of works about the behavior and mechanical performance of concretes manufactured with recycled aggregates (1-10); on the other hand and more recently, concretes with addition of SCM are currently providing knowledge (11-15), giving emphasis to the favorable impact of SCM in the mechanical behavior and in the environmental benefit. Due to their components nature, the concrete manufactured with recycled material present different microstructure and greater porosity than the conventional concrete (16-19); it is also known that the electrical resistivity of the concrete is related to the microstructure of the cementitious matrix and to their pores 
distribution (20-22). This last property has been recognized as an important parameter to evaluate the concrete durability.

In order to verify the behavior of reinforced concrete manufactured with recycled aggregates and with SCM, the electrical and electrochemical response are analyzed by means of the Electrochemical Impedance Spectroscopy technique (EIS), recognized as an efficient method to evaluate the dielectric and electrochemical properties in resistive systems (as the case of reinforced concrete).

\section{Experimental work}

It was produced four sets of specimens with water-cementitious material ratio of 0.48 : reference series made with natural aggregate (NA) and 100\% Composite Portland Cement (CPC) (23), series made with recycled coarse aggregate (RCA) and $100 \%$ CPC, series made with RCA and 30\% FA as a partial replacement of the CPC, and finally, series made with RCA and $10 \%$ SF as a partial replacement of the CPC.

\section{$\underline{\text { Materials }}$}

RCA comes from the crushing of concrete specimens made with natural aggregates, CPC with a water-cement ratio of 0.50 and curing for a 28-day period with controlled temperature and relative humidity $(\mathrm{RH})$ of $23 \pm 2{ }^{\circ} \mathrm{C}$ and $98 \pm 1 \%$. Natural aggregates come from quarry crushed rock (coarse) and river sand (fine). Table I shows some of the physical properties of these aggregates.

TABLE I. Pphysical properties of the aggregates used in concrete mixtures.

\begin{tabular}{cccccc}
\hline $\begin{array}{c}\text { Type of } \\
\text { aggregate }\end{array}$ & $\begin{array}{c}\text { Relative } \\
\text { density }\end{array}$ & $\begin{array}{c}\text { Absorption } \\
\left(\mathbf{g} / \mathbf{c m}^{\mathbf{3}}\right)\end{array}$ & $\begin{array}{c}\text { Humidity } \\
\mathbf{( \% )}\end{array}$ & $\begin{array}{c}\text { Fineness } \\
\text { module }\end{array}$ & $\begin{array}{c}\text { Maximum } \\
\text { size }\end{array}$ \\
\hline $\begin{array}{c}\text { Recycled } \\
\text { coarse }\end{array}$ & 2.19 & 6.55 & 2.14 & $\mathbf{( \% )}$ & $\mathbf{( m m )}$ \\
$\begin{array}{c}\text { Natural } \\
\text { coarse }\end{array}$ & 2.50 & 0.44 & 0.28 & - & 19 \\
$\begin{array}{c}\text { Natural } \\
\text { fine }\end{array}$ & 2.43 & 4.08 & 6.66 & 2.73 & 4.76 \\
\hline
\end{tabular}

As SCM, Mexican Class F FA according to ASTM C618 (24) and SF North-American with the requirements of ASTM C1240 (25) were used. Table II shows the physical and chemical properties of these materials. 
TABLE II. Physico-chemical properties of cementitious materials.

\begin{tabular}{|c|c|c|c|c|c|c|c|c|}
\hline \multicolumn{9}{|c|}{ Chemical composition (\% of weight) } \\
\hline Material & $\mathrm{SiO}_{2}$ & $\mathbf{A l}_{2} \mathbf{O}_{3}$ & $\mathrm{Fe}_{2} \mathrm{O}_{3}$ & $\mathrm{CaO}$ & $\mathrm{SO}_{3}$ & $\mathrm{~K}_{2} \mathrm{O}$ & $\mathrm{Na}_{2} \mathrm{O}$ & MgO \\
\hline СРC & 19.94 & 4.40 & 2.97 & 63.50 & 3.08 & 0.42 & 0.12 & - \\
\hline FA & 58.84 & 16.72 & 3.52 & 7.35 & 0.13 & 0.79 & 0.94 & 1.76 \\
\hline SF & 95.22 & 0.08 & 2.37 & 0.26 & 0.11 & 0.56 & 0.30 & 0.24 \\
\hline \multicolumn{9}{|c|}{ Physical properties } \\
\hline & \multicolumn{2}{|c|}{ Density $\left(\mathrm{g} / \mathrm{cm}^{3}\right)$} & \multicolumn{3}{|c|}{ Specific surface, BET (m²/kg) } & \multicolumn{3}{|c|}{ Average size $(\boldsymbol{\mu m})$} \\
\hline CPC & \multicolumn{2}{|c|}{3.15} & \multicolumn{3}{|c|}{1400} & \multicolumn{3}{|c|}{$15-25$} \\
\hline FA & \multicolumn{2}{|c|}{2.35} & \multicolumn{3}{|c|}{1200} & \multicolumn{3}{|c|}{ 5-15 } \\
\hline SF & \multicolumn{2}{|c|}{2.27} & \multicolumn{3}{|c|}{19600} & \multicolumn{3}{|c|}{$0.1-0.2$} \\
\hline
\end{tabular}

\section{Dielectric and Electrochemical Properties}

To evaluate the electrical resistivity and corrosion resistance of the systems studied were prepared two cylindrical specimens (length $=15 \mathrm{~cm}$, diameter $=15 \mathrm{~cm}$ ) for each mixture, its characteristics and proportions are presented in Table III. These specimens were cured for 28 days in a chamber with temperature of $23 \pm 2{ }^{\circ} \mathrm{C}$ and $98 \pm 1 \%$ of $\mathrm{RH}$.

TABLE III. Characteristics and proportion of the test mixtures (by $1 \mathrm{~m}^{3}$ of concrete).

\begin{tabular}{c|c|ccc}
\hline \multirow{2}{*}{$\begin{array}{c}\text { Materials } \\
(\text { Kg) }\end{array}$} & $\begin{array}{c}\text { Natural coarse } \\
\text { and fine aggregate }\end{array}$ & Recycled coarse aggregate, natural sand and SCM \\
\cline { 2 - 4 } & NA 100\% CPC & RA 100\% CPC & RA 30\% FA & RA 10\% SF \\
\hline Water & 213.31 & 213.31 & 213.31 & 213.31 \\
Gravel & 994.55 & 870.58 & 870.58 & 870.58 \\
Sand & 766.17 & 915.35 & 915.35 & 915.35 \\
Cement & 444.44 & 444.44 & 311.11 & 400.00 \\
SCM & 0.000 & 0.000 & 133.33 & 44.44 \\
\hline
\end{tabular}

Each specimen had two embedded bars of 1018 carbon steel $\Phi=9.5 \mathrm{~mm}$ and with an exposed area of $64 \mathrm{~cm}^{2}$, localized $4.5 \mathrm{~cm}$ from the outside. The steel bars were cleaned before placement for corrosion test. The specimens were exposed to an aqueous solution of $3.5 \% \mathrm{NaCl}$ to assess both: the change in the electrolytic resistance (Re), which has correlation with the concrete resistivity ( $\rho$ ); and the variation in the Resistance of charge transfer (Rct), which has correlation with the corrosion current density ( $\mathrm{i}_{\text {corr }}$ ) of reinforcement. 
The evaluation of parameters Re and Rct, was accomplished by EIS in a potentiostat/Galvanostat/FRA of ACM Instruments, the test parameters were a $10 \mathrm{mV}$ amplitude potential to maintain the system linearity in a frequency range of $1 \mathrm{mHz}$ to 10 kHz. The experimental testing is shown in Figure 1.

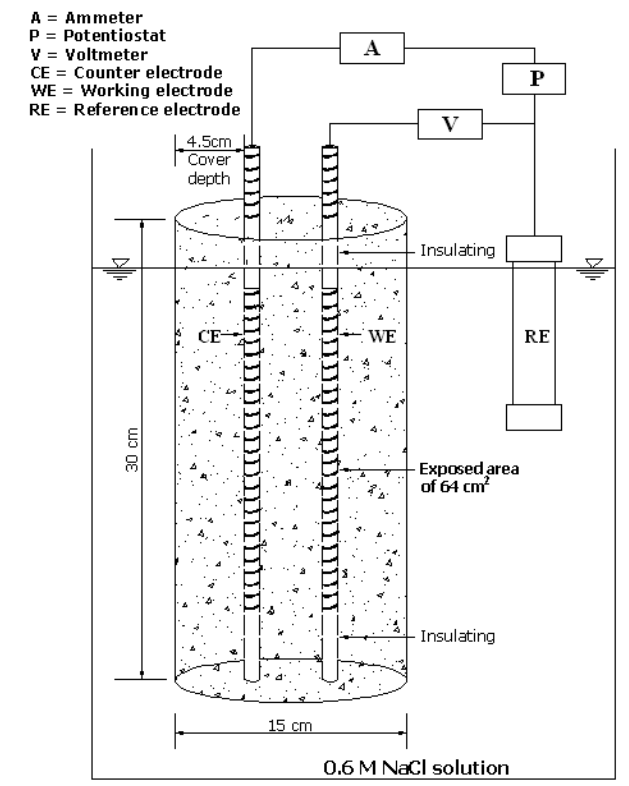

Figure 1. Experimental scheme for testing EIS.

The EIS results were represented with Nyquist diagrams [Figure 2 a)], and an equivalent circuit (EC) Randles type (shown in Figure 2 b) was used to determine accurately the intersection value at low frequencies and can calculate the Rct.

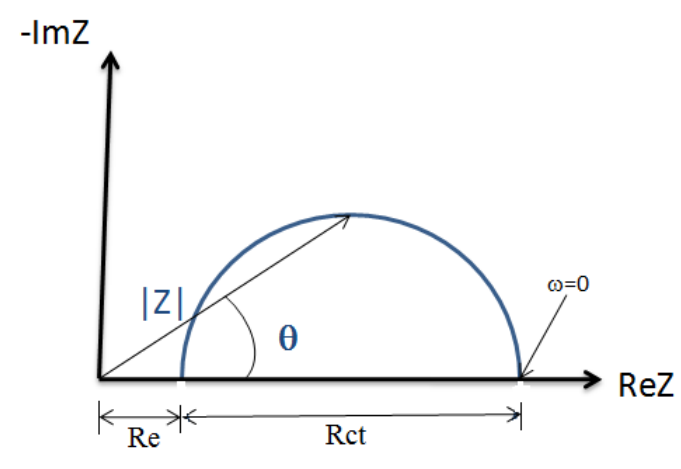

a)

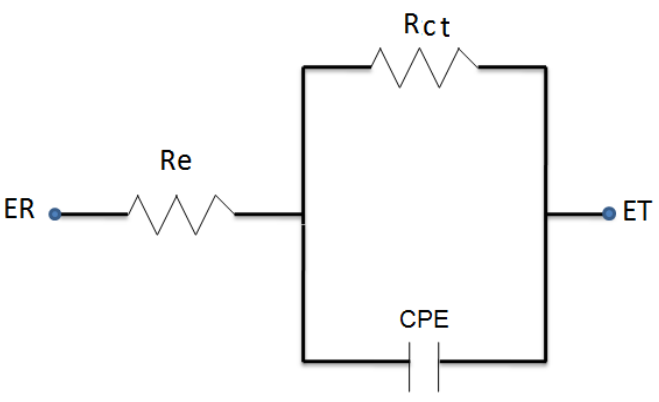

b)

Figure 2. a) Ideal Nyquist diagram, b) EC used to simulate experimental results of EIS.

The calculated Rct and the Re obtained from the intersection at high frequencies with the Nyquist diagram were used to determine $i_{\text {corr }}$ and concrete electrical resistivity $(\rho)$, respectively. Using Equation 1 (26), $\mathrm{i}_{\text {corr }}$, was calculated; where $\mathrm{B}$ is the Tafel constant with recommended value (27-30) of $0.052 \mathrm{~V}$ for the passive corrosion of steel in 
concrete; $\rho$ was determined from Equation 2, where Cc is a cell constant that depends on the geometry of the conducting body (31).

$$
\begin{aligned}
& i_{\text {corr }}=\frac{B}{R c t} \\
& \operatorname{Re}=\rho \cdot C_{c}
\end{aligned}
$$

$\mathrm{C}_{\mathrm{c}}$ is a cell constant $(58,47 \mathrm{~cm}), \mathrm{L}$ is the submerged length of the reinforced concrete specimen $(20 \mathrm{~cm}), \mathrm{D}$ is the concrete specimen diameter $(15 \mathrm{~cm}), \mathrm{d}$ is the steel reinforcement diameter $(0.95 \mathrm{~cm})$ and $\mathrm{z}$ is the distance between the concrete specimen and reinforcement $(5.05 \mathrm{~cm})$. The cell constant $\mathrm{C}_{\mathrm{c}}$ was determined analytically (Equation 3) applying the principles of heat conduction through the elements proposed by Sunderland and Johnson (32). The Laplace equation was resolved considering as limit the steel elements temperature (Reinforcement) $T_{1}$, and the concrete elements temperature $T_{2}$, where $T_{1}=T_{2}=$ constant.

$$
C_{c}=\left(\frac{2 \pi L}{\cosh ^{-1}\left(\frac{D^{2}+d^{2}-4 z^{2}}{2 D d}\right)}\right)
$$

\section{Results and discussion}

Dielectric and electrochemical properties of concrete-steel systems with a 90-days exposure are represented in the Nyquist diagram of Figure 3; it shows that the RA 100\% CPC system has minimum values of Rct and Re, while the RA 10\% SF system reaches the maximum. The $\rho$ as a function of the exposure time, shown in Figure 4, denotes that the use of RCA results from a decrement in the concrete resistivity. In both systems, NA $100 \%$ CPC and RA 100\% CPC, $\rho$ unsurpassed the limit of $10 \mathrm{k} \Omega$-cm indicating that it is not the controlling parameter of corrosion rate; and therefore there is a high risk that the phenomenon should present in them $(22,33)$. In the SCM systems, it is remarkable the positive effect of them on the concrete resistivity; the $\rho$ in the RA 30\% FA system is slightly higher than the limit value, while the RA 10\% SF system exceeds it largely, allowing to predict a moderate or low likelihood of beginning the corrosion. The increase in $\rho$ in SCM systems is attributed to the densification of porous system (because the ionic conduction is through pore structure of cementitious matrix), generated by the increase in the formation of calcium silicate hydrates (CSH) and the reduction in the formation of $\mathrm{Ca}(\mathrm{OH})_{2}$ product of the pozzolanic reaction between the last one with the $\mathrm{SiO}_{2}$ content in the SCM. Table II shows that the SF is approximately 100 times finer than cement and FA, providing much $\mathrm{SiO}_{2}$. Because hydration and pozzolanic reactions are surface phenomena, it is deduced that the microstructure of concrete with SF becomes denser 
than the rest of the systems due to the production of more $\mathrm{CSH}$ which replaces $\mathrm{CH}$ and generates pore refinement, and therefore, it reports an increase in its electrical resistivity. Moreover, in the first three months of the test, the $\rho$ in SCM systems increases rapidly, whereas after this period it slows down, thus suggesting that such reactions come to equilibrium after about a 90-day period of exposure.

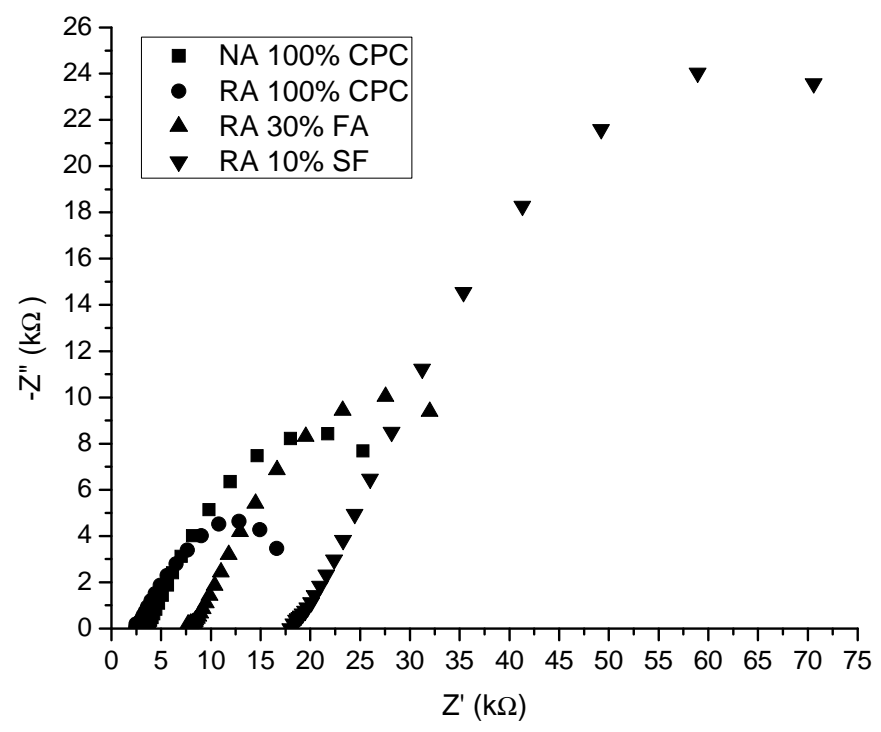

Figure 3. Nyquist diagram for concrete-steel systems within 90 days of exposure.

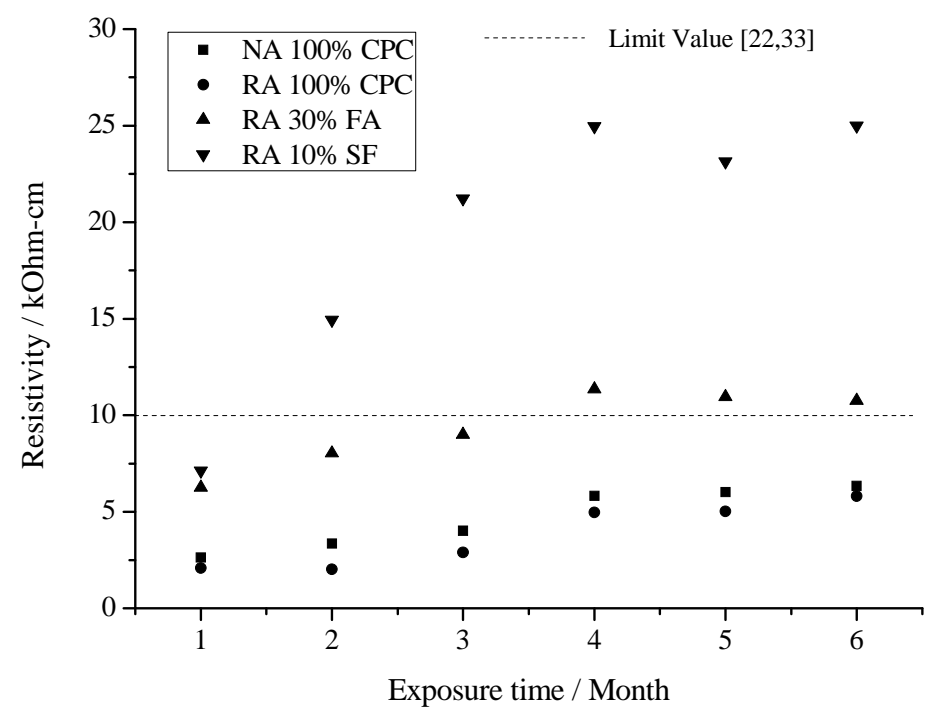

Figure 4. Evolution of electrical resistivity as a function of exposure time 
The determined results of $i_{\text {corr, }}$ from the obtained values of Rct, are shown in Figure 5, in this figure is possible to compare the corrosion resistance values in concrete-steel systems used in this study. In a general perspective, during the third-test month, an inflexion point is located between two corrosion states with different activity level; this division is attributed to, from this point, the reactions of hydration-pozzolanic in the cement and SCM reach equilibrium and their speed is stabilized. It is also noted that the system with greater corrosion resistance is the RA $10 \% \mathrm{SF}$, since despite its corrosive activity was greatest in the first month, it decreased significantly during the subsequent months until reaching a minimum level of corrosion $\left(0.004 \mu \mathrm{A} \mathrm{cm}{ }^{-2}\right)$ at the sixth month of trial, with an average of $0.025 \mu \mathrm{A} \mathrm{cm} \mathrm{cm}^{-2}$ in all its trial period. Moreover, the RA $100 \%$ CPC system reported its maximum corrosion levels (from 0.044 to $0.060 \mu \mathrm{A} \mathrm{cm}{ }^{-2}$ ) until the third month, although in the last three months its corrosive activity is significantly reduced in an average of $i_{\text {corr }}$ for this period of $0.031 \mu \mathrm{A} \mathrm{cm}{ }^{-2}$, classifying it as the system with less corrosion resistance. The RA 30\% FA system reported low corrosion levels till the second test month (from 0.022 to $0.037 \mu \mathrm{A} \mathrm{cm}{ }^{-2}$ ), maintaining this activity at the same level for the subsequent months, the average $i_{\text {corr }}$ was $0.025 \mu \mathrm{A} \mathrm{cm}{ }^{-2}$, similar to that obtained by the RA $10 \%$ SF system. The mentioned results show that although there is a significant difference in terms of $\rho$ in the SCM systems, the corrosion resistance can be equivalent. This is attributable to the high content of $\mathrm{Al}_{2} \mathrm{O}_{3}(\cong 17 \%)$ in the FA with respect to $\mathrm{SF}(\cong 0.1 \%)$ and cement $(\cong 4 \%)$. In a X-rays study by Koulombi et al (34), it was demonstrated that the addition of FA generates a higher content of chloroaluminate (Friedel salt), and consequently, lower levels of free chlorides, which are responsible in this case of the localized reinforcing steel corrosion.

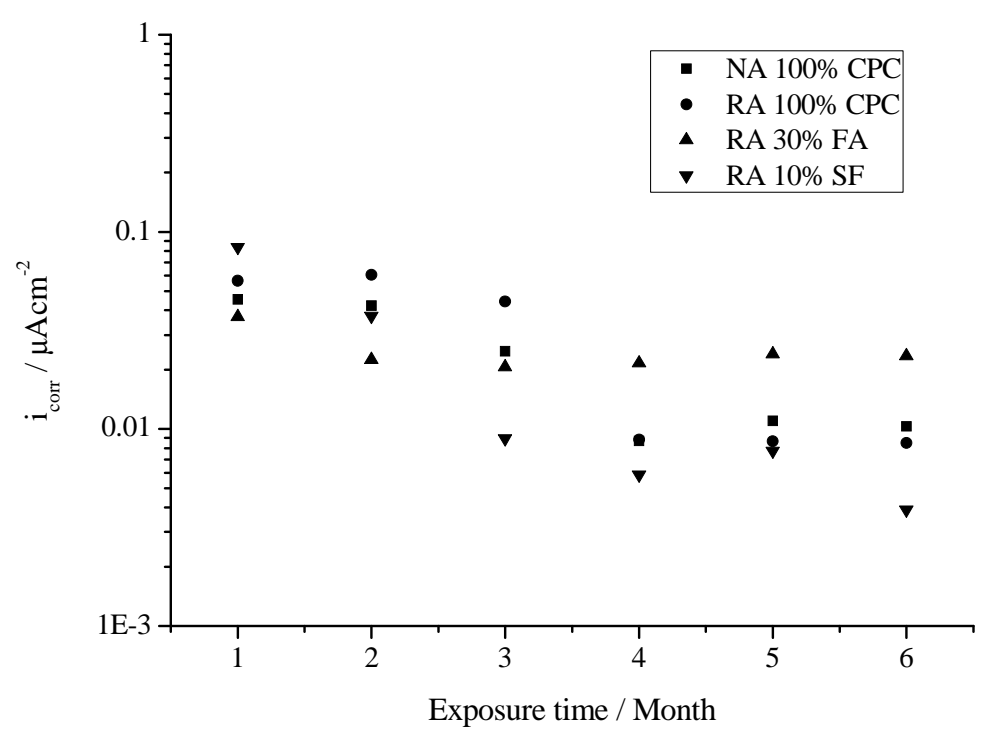

Figure 5. Variation in the corrosion current density as a function of the exposure time. 


\section{Conclusions}

According to the experimental conditions of this study, it is possible to conclude:

- The use of $100 \%$ recycled aggregate, decreases concrete electrical resistivity, increasing then the corrosion rate of reinforcement.

- Fly ash and silica fume contribute significantly in increase the concrete electrical resistivity, causing a cementing matrix densification and refinement of pores.

- Although the magnitude of the electrical resistivity in a concrete with silica fume, is two times larger than that of a concrete with fly ash; the corrosion resistance in both is very similar due to the high content of $\mathrm{Al}_{2} \mathrm{O}_{3}$ in the fly ash compared to silica fume.

- The use of fly ash and silica fume increase the durability of concretes with $100 \%$ recycled coarse aggregate, being this feasible to use in structures exposed to aggressive environments, contributing to the concrete industry sustainability.

- It is possible to ascertain both: degree and hydration mechanism in a cementing paste of a concrete, determining the electrical resistivity by electrochemical impedance spectroscopy.

\section{Acknowledgements}

To the Autonomous University of Sinaloa, and the Advanced Materials Research Centre, SC, for the given help. Also, to CONACYT, for its Ph Degree scholarship program.

\section{References}

1. Ajdukiewicz, A. Kliszczewicz, Cement and Concrete Composites, 24, 269 (2002).

2. H. Chen, T. Yen, K. Chen, Cement and Concrete Research, 33, 125 (2003).

3. A. Katz, Cement and Concrete Research, 33, 703 (2003).

4. C.S. Poon, Z.H. Shui, L. Lam, H. Fok, S.C. Kou, Cement and Concrete Research, 34, 31 (2004).

5. I. Topçu, S. Sengel, Cement and Concrete Research, 34, 1307 (2004).

6. T. Tu, Y. Chen, C. Hwang, Cement and Concrete Research, 36, 943 (2006).

7. I. Martínez, C. Mendoza, Ingeniería Investigación y Tecnología, 7, 151 (2006).

8. K. Rahal, Building and Environment, 42, 407 (2007).

9. M. Casuccio, M.C. Torrijos, G. Giaccio, R. Zerbino, Construction and Buildings Materials, 22, 1500 (2008). 
10. A.K. Padmini, K. Ramamurthy, M.S. Mathews, Construction and Buildings Materials, 23, 829 (2009).

11. K.Y. Ann, H.Y. Moon, Y.B. Kim, J. Ryou, Waste Management, 28, 993 (2008).

12. B. González, F. Martínez, Building and Environment, 43, 429 (2008).

13. S.C. Kou, C.S. Poon, D. Chan, Materials and Structures, 41, 1191 (2008).

14. M.L. Berndt, Construction and Buildings Materials, 23, 2606 (2009).

15. V. Corinaldesi, G. Moriconi, Construction and Buildings Materials, 23, 2869 (2009).

16. J.M.V. Gómez, Cement and Concrete Research, 32, 1301 (2002).

17. C.S. Poon, Z.H. Shui, L. Lam, Construction and Buildings Materials, 18, 461 (2004).

18. V.W.Y. Tam, X.F. Gao, C.M. Tam, Cement and Concrete Research, 35, 1195 (2005).

19. M. Etxeberría, E. Vazquez, A. Mari, Magazine of Concrete Research, 58, 683 (2006).

20. P.J. Tumidajski, A.S. Shumacher, S. Perron, P. Gu, J.J. Beaudoin, Cement and Concrete. Research, 26, 539 (1996).

21. P.J. Tumidajski, Cement and Concrete Research, 35, 1262 (2005).

22. R. Polder, C. Andrade, B. Elsener, O.E. Vennesland, J. Gulikers, R. Weidert, M. Raupach, Materials and Structures, 33, 603 (2000).

23. ONNCCE, NMX-C-414-04, Especificaciones y métodos de prueba del cemento hidráulico, Instituto Mexicano del Cemento y el Concreto México, (2004).

24. ASTM International. ASTM C618-99, Standard Specification for Coal Fly Ash for Use as a Mineral Admixture in Concrete. ASTM International, (1999).

25. ASTM International, ASTM C1240-05, Standard Specification for Silica Fume Used in Cementitious Mixtures. ASTM International, (2005).

26. M. Stern, A. Geary, Journal of the electrochemical society, 104, 56 (1957).

27. R.K. Dhir, M.R. Jones, M.J. McCarthy, Cement and Concrete Research, 23, 1443 (1993).

28. J.A. González, E. Ramírez, A. Bautista, S. Feliú, Cement and Concrete Research, 26, 501 (1996).

29. K.R. Gowers, S.G. Millard, Corrosion Science, 35, 1593 (1993).

30. P.S. Mangat, B.T. Molloy, Materials and Structures, 25, 404 (1992). 
31. J.M. Torrents, J. Roncero, R. Gettu, Cement and Concrete Research, 28, 1325 (1998).

32. J.E. Sunderland, K.R. Johnson, ASHRAE $71^{\text {st }}$ Annual Meeting, Cleveland (1964).

33. C. Andrade, C. Alonso, Construction and Building Materials, 10, 15 (1996).

34. N. Koulombi, G. Batis, C.H. Malami, Progress in the understanding and prevention of corrosion, Mercer AD editors, Institute of Materials, Spain, 619 (1993). 